Gut, 1963, 4, 112

\title{
The relationship between acid secretion after augmented histamine stimulation and the histology of the gastric mucosa
}

\author{
O. A. A. BOCK, W. C. D. RICHARDS, AND L. J. WITTS \\ From the Nuffield Department of Clinical Medicine and the Department \\ of Morbid Anatomy, the Radcliffe Infirmary, Oxford
}

EDITORIAL SYNOPSIS Augmented histamine tests and gastric mucosal biopsies were performed on 97 patients.

The amount of acid secreted was closely correlated with the histological appearances of the gastric mucosa. There was a striking difference between the acid secretion of patients with normal biopsies and patients with superficial gastritis.

Achlorhydria was not present in patients with normal biopsies. An occasional patient with gastric atrophy will be found to secrete small amounts of acid.

Joske, Finckh, and Wood (1955) noted that the amount of acid secreted by 784 patients after the injection of $0.3 \mathrm{mg}$. histamine could be closely correlated with the histological appearances of the gastric mucosal biopsies. With increase of the inflammatory reaction and atrophy of the gastric mucosa there was a corresponding fall in the acid secretion; and whereas achlorhydria occurred in 37 of the 275 patients with normal biopsies, only two of the 41 patients with gastric atrophy did not have achlorhydria. Others (Wood, Doig, Motteram, Weiden, and Moore, 1949; Funder and Weiden, 1952; Poliner and Spiro, 1958; Glass, Speer, Nieburgs, Ishimori, Jones, Baker, Schwartz, and Smith, 1960) made similar observations when using histamine in doses varying between $0.3 \mathrm{mg}$. and $1.0 \mathrm{mg}$.

Davidson and Markson (1955) compared the frequency of achlorhydria after the injection of $2 \mathrm{mg}$. histamine with the gastric biopsies of 73 patients suffering from either iron-deficiency anaemia or diseases not affecting the alimentary tract. Normal biopsies were found in 34 patients, of whom only one had achlorhydria, while seven out of eight patients with gastric atrophy had achlorhydria. Fourteen patients had superficial gastritis and 17 patients had atrophic gastritis; achlorhydria was detected in five $(36 \%)$ of the former group and in $11(65 \%)$ of the latter group.

In the present paper we report our observations on the relationship between the histology of the gastric mucosa and the amount of acid secreted in response to augmented histamine stimulation, which is probably the most reliable quantitative test of gastric secretory capacity.

\section{MATERIAL}

Ninety-seven patients were studied. They suffered from iron-deficiency anaemia, pernicious anaemia, steatorrhoea, thyrotoxicosis, myxoedema, or diabetes mellitus. Barium meal examinations were carried out on 83 of them and none had evidence of peptic ulceration.

\section{METHODS}

GASTRIC BIOPSIES These were performed with a modified Wood's tube. The sections were stained with haematoxylin and eosin and classified into normal, superficial gastritis, atrophic gastritis, and gastric atrophy.

Superficial gastritis There was inflammatory cell infiltration of the mucosa, often with distortion of the superficial layers, but there was no evidence of atrophy of the specific cells.

Atrophic gastritis There was inflammatory cell infiltration of the mucosa with variable, but not complete, atrophy of the specific cells. Islands of intestinal metaplasia were sometimes present.

Gastric atrophy Atrophy of the specific cells was severe or complete, intestinal metaplasia was often conspicuous, and there was little or no inflammatory cell infiltration of the mucosa.

A more detailed account of the histological features for each classification has been given elsewhere (Bock, Arapakis, Witts, and Richards, 1963). 
AUGMENTED HISTAMINE TEST The test was performed as originally described by Kay (1953) with minor modifications. Only $50 \mathrm{mg}$. mepyramine maleate was given and this was injected intramuscularly half an hour before the subcutaneous injection of $0.04 \mathrm{mg}$. per kilogram body weight histamine acid phosphate. The collection of juice was continued for another hour. Continuous hand suction was used throughout and the patency of the aspiration tube was ensured by blowing air through it at intervals. No attempt was made to block the pylorus to prevent gastric juice escaping or duodenal juice entering the stomach because it has been shown that this cumbersome procedure makes little difference, provided continuous suction is used (Ihre, 1956; Marks, 1957; Kyle and Stephens, 1961).

The volume of each specimen was measured and the milliequivalents per litre of hydrochloric acid (mEq./l.) were determined by titrating $1 \mathrm{ml}$. aliquots of juice to pH 7.0 with $0.1 \mathrm{~N}$ sodium hydroxide. An Electrical Instruments Limited model $23 \mathrm{~A}$ direct reading $p \mathrm{H}$ meter with microcell attachment was used.

The results of the tests were expressed as the volume of juice and the total milliequivalents of acid (total $\mathrm{mEq}$. $\mathrm{HCl}$ ) secreted in one hour after augmented histamine stimulation. Achlorhydria is defined as that condition in which the total $\mathrm{mEq}$. $\mathrm{HCl}$ secreted is zero (Bock, 1962).

\section{RESULTS}

The results of the augmented histamine tests and gastric biopsies performed on the 97 patients are summarized in Table I.
The most surprising result was the difference between the mean total $\mathrm{mEq}$. $\mathrm{HCl}$ of the patients with normal biopsies and that of the patients with superficial gastritis: the latter secreted 10.00 $\pm 7 \cdot 60$ total $\mathrm{mEq}$. $\mathrm{HCl}$ in one hour after augmented histamine stimulation whereas the patients with normal biopsies secreted more than twice as much, $22.00 \pm 15.00$ total $\mathrm{mEq}$. $\mathrm{HCl}(\mathrm{P}<0.001)$. The mean volume of gastric juice secreted by the patients with superficial gastritis was also significantly lower $(\mathrm{P}<0.01)$ than that of the persons with normal biopsies. Age cannot account for the differences, because the mean ages of the two groups are similar, and the mean haemoglobin concentration of the two groups is not very different.

A more detailed analysis of the results is given in Table II. The males with normal biopsies secreted significantly more acid than the females with normal biopsies $(P<0.05)$, but the mean acid secretion of the males with superficial gastritis and atrophic gastritis was not strikingly different from the females with superficial gastritis and atrophic gastritis.

Two of the 14 patients with gastric atrophy secreted small amounts of acid. One was a 57-yearold man with diabetes mellitus who secreted 0.25 total $\mathrm{mEq}$. $\mathrm{HCl}$ and $20 \mathrm{ml}$. juice in the hour after the injection of $2.0 \mathrm{mg}$. histamine acid phosphate, the $p \mathrm{H}$ of the juice falling to 5.035 minutes after the injection. His serum vitamin B12 was $175 \mu \mu \mathrm{g}$./

\section{TABLE I}

COMPARISON BETWEEN HISTOLOGICAL APPEARANCES OF GASTRIC MUCOSA, VOLUME OF GASTRIC JUICE AND AMOUNT OF ACID SECRETED BY 97 PATIENTS AFTER AUGMENTED HISTAMINE STIMULATION

\begin{tabular}{|c|c|c|c|c|c|c|c|c|c|c|c|}
\hline Histology & No. & $\begin{array}{l}\text { Mean } \\
\text { Age } \\
(y r .)\end{array}$ & $\begin{array}{l}\mathrm{Hb} \\
(\mathrm{g} . / 100 \\
\mathrm{ml} .)\end{array}$ & $\begin{array}{c}\text { Standard } \\
\text { Deviation }\end{array}$ & $\begin{array}{l}\text { Student's } \\
t \text { Test }\end{array}$ & $\begin{array}{l}\text { Mean } \\
\text { Total } \\
\text { mEq. } \mathrm{HCl}\end{array}$ & $\begin{array}{l}\text { Standard } \\
\text { Deviation }\end{array}$ & $\begin{array}{l}\text { Student's } \\
t \text { Test }\end{array}$ & $\begin{array}{l}\text { Mean } \\
\text { Volume } \\
(\mathrm{ml} .)\end{array}$ & $\begin{array}{l}\text { Standard } \\
\text { Deviation }\end{array}$ & $\begin{array}{l}\text { Student's } \\
t \text { Test }\end{array}$ \\
\hline Superficial gastritis & 25 & 36 & $12 \cdot 1$ & $\pm 3 \cdot 2$ & & $10 \cdot 00$ & \pm 7.60 & & 116 & \pm 61 & \\
\hline Atrophic gastritis & 22 & 49 & $12 \cdot 9$ & $\pm \mathbf{2 \cdot 2}$ & & $3 \cdot 54$ & \pm 6.20 & & 61 & \pm 72 & \\
\hline Gastric atrophy & 14 & 50 & $11 \cdot 9$ & $\pm 2 \cdot 4$ & & 0.02 & \pm 0.06 & & 11 & \pm 11 & \\
\hline
\end{tabular}

TABLE II

COMPARISON BETWEEN HISTOLOGICAL APPEARANCE OF GASTRIC MUCOSA, SEX OF THE PATIENT, VOLUME OF GASTRIC JUICE, AMOUNT OF ACID SECRETED, AND FREQUENCY OF ACHLORHYDRIA

\begin{tabular}{|c|c|c|c|c|c|c|c|c|c|c|}
\hline \multirow[t]{2}{*}{ Histology } & \multirow[t]{2}{*}{ Sex } & \multirow[t]{2}{*}{ No. } & \multicolumn{2}{|c|}{ Total $\mathrm{mEq} . \mathrm{HCl}$} & \multicolumn{2}{|c|}{ Volume (ml.) } & \multirow{2}{*}{$\begin{array}{l}\text { No. with } \\
\text { Achlor- } \\
\text { hydria }\end{array}$} & \multirow{2}{*}{$\begin{array}{l}\text { Total No. } \\
\text { of Patients }\end{array}$} & \multirow{2}{*}{$\begin{array}{l}\text { Total No. } \\
\text { with } \\
\text { Achlor- } \\
\text { hydria }\end{array}$} & \multirow{2}{*}{$\begin{array}{l}\% \\
\text { Achlor- } \\
\text { hydria }\end{array}$} \\
\hline & & & Mean & Range & Mean & Range & & & & \\
\hline Normal & $\begin{array}{l}\mathbf{M} \\
\mathbf{F}\end{array}$ & $\begin{array}{l}15 \\
21\end{array}$ & $\begin{array}{l}28 \cdot 80 \\
17 \cdot 10\end{array}$ & $\begin{array}{r}10 \cdot 70-77 \cdot 40 \\
2 \cdot 57-46 \cdot 75\end{array}$ & $\begin{array}{l}233 \\
153\end{array}$ & $\begin{array}{l}98-610 \\
30-362\end{array}$ & $\begin{array}{l}\mathbf{0} \\
\mathbf{0}\end{array}$ & 36 & 0 & $\mathbf{0}$ \\
\hline Superficial gastritis & $\begin{array}{l}\mathbf{M} \\
\mathbf{F}\end{array}$ & $\begin{array}{r}5 \\
20\end{array}$ & $\begin{array}{r}11 \cdot 70 \\
9 \cdot 60\end{array}$ & $\begin{array}{r}1 \cdot 93-21 \cdot 59 \\
0-31 \cdot 55\end{array}$ & $\begin{array}{l}124 \\
113\end{array}$ & $\begin{array}{r}44-193 \\
0-271\end{array}$ & $\begin{array}{l}0 \\
1\end{array}$ & 25 & 1 & 4 \\
\hline Atrophic gastritis & $\begin{array}{l}\mathbf{M} \\
\mathbf{F}\end{array}$ & $\begin{array}{r}5 \\
17\end{array}$ & $\begin{array}{l}5 \cdot 60 \\
3 \cdot 17\end{array}$ & $\begin{array}{l}0-2 C \cdot 56 \\
0-18 \cdot 63\end{array}$ & $\begin{array}{l}89 \\
52\end{array}$ & $\begin{array}{r}25-252 \\
4-263\end{array}$ & $\begin{array}{l}1 \\
6\end{array}$ & 22 & 7 & 32 \\
\hline Gastric atrophy & $\begin{array}{l}\mathbf{M} \\
\mathbf{F}\end{array}$ & $\begin{array}{l}5 \\
9\end{array}$ & $\begin{array}{l}0.05 \\
0.01\end{array}$ & $\begin{array}{l}0-0.25 \\
0-0.02\end{array}$ & $\begin{array}{r}24 \\
5\end{array}$ & $\begin{array}{l}4-54 \\
0-11\end{array}$ & $\begin{array}{l}4 \\
8\end{array}$ & 14 & 12 & 87 \\
\hline
\end{tabular}


TABLE III

REPORTED RESULTS OF AUGMENTED HISTAMINE TEST (TOTAL $\mathrm{mEq}$. $\mathrm{HCl}$ PER HOUR-MAXIMUM ACID OUTPUT) PERFORMED ON NORMAL PERSONS COMPARED WITH RESULTS IN 36 PATIENTS WITH NORMAL GASTRIC BIOPSIES Author(s)

\begin{tabular}{|c|c|c|c|c|c|}
\hline \multicolumn{3}{|c|}{ Males } & \multicolumn{3}{|c|}{ Females } \\
\hline No. & Mean & Range & No. & Mean & Range \\
\hline 27 & $22 \cdot 20$ & & & & \\
\hline 14 & $22 \cdot 40$ & $10 \cdot 10-34 \cdot 60$ & 18 & $14 \cdot 60$ & $0 \cdot 10-31 \cdot 30$ \\
\hline 31 & $23 \cdot 20$ & & 15 & 15.00 & \\
\hline 29 & $22 \cdot 65$ & $10 \cdot 10-41 \cdot 50$ & 28 & $17 \cdot 20$ & $6 \cdot 20-34 \cdot 60$ \\
\hline 30 & $23 \cdot 30$ & & 12 & $17 \cdot 70$ & \\
\hline 15 & 28.80 & $10 \cdot 70-77 \cdot 40$ & 21 & $17 \cdot 10$ & $2 \cdot 57-46 \cdot 75$ \\
\hline
\end{tabular}

$\mathrm{ml}$. and his absorption of radioactive vitamin $\mathrm{B} 12$ was normal. The other patient was a 72-year-old woman who secreted 0.02 total $\mathrm{mEq} . \mathrm{HCl}$ and $5 \mathrm{ml}$. of juice during the augmented histamine test, the $p \mathrm{H}$ of the collected juice being 6.6. She fulfilled all the other criteria for the diagnosis of pernicious anaemia and, in particular, her absorption of radioactive vitamin B12 was much enhanced by the addition of intrinsic factor.

The frequency of achlorhydria in the 97 patients is shown in Table II. Achlorhydria was not found in any of the 36 patients who had normal biopsies but one of the 25 patients with superficial gastritis had achlorhydria. This patient was a 14-year-old girl with thyrotoxicosis who secreted 12.08 total $\mathrm{mEq}$. $\mathrm{HCl}$ and $141 \mathrm{ml}$. when another augmented histamine test was performed three days later.

\section{DISCUSSION}

The results of this study clearly show that the amount of acid secreted in response to the injection of large doses of histamine can be correlated with the histology of the gastric mucosa. Achlorhydria after augmented histamine stimulation must be extremely rare in persons who have normal gastric mucosae. It is now generally accepted that achlorhydria in the augmented histamine test is an important feature of pernicious anaemia (Callender, Retief, and Witts, 1960), but when the augmented histamine test is carefully performed and the collected juice is titrated electrometrically, an occasional patient with pernicious anaemia and/or severe atrophic gastritis or gastric atrophy will be found to secrete minimal amounts of acid.

In Table III the mean total $\mathrm{mEq} . \mathrm{HCl}$ and the range of acid secretion of the 36 patients with normal biopsies are compared with the values observed for normal persons by other investigators using the augmented histamine test. The mean total $\mathrm{mEq}$. $\mathrm{HCl}$ of the females of this study is the same as that of the two most recent reports, whereas the mean total $\mathrm{mEq}$. $\mathrm{HCl}$ of the males is higher than that of the other studies. Table III also indicates that the lower limit of acid secretion for normal women is less clearly defined than the lower limit for normal men, which is about 10 total $\mathrm{mEq}$. $\mathrm{HCl}$ per hour after augmented histamine stimulation.

\section{REFERENCES}

Bock, O. A. A. (1962). Some tests of gastric function and their application in thyrotoxicosis and diabetes mellitus. D.M. thesis, Oxford.

—, Arapakis, G., Witts, L. J., and Richards, W. C. D. (1963). The serum pepsinogen level with special reference to the histology of the gastric mucosa. Gut, 4, 106-111.

Bruce, J., Card, W. I., Marks, I. N., and Sircus, W. (1959). The rationale of selective surgery in the treatment of duodenal ulcer. J. roy. Coll. Surg. Edinb., 4, 85-104.

Callender, S. T., Retief, F. P., and Witts, L. J. (1960). The augmented histamine test with special reference to achlorhydria. Gut, 1, 326-336.

Card, W. I., and Sircus, W. (1960). Quoted by Smith, A. W. M., Delamore, I. W., and Williams, A. W., 1961. Gastric acid secretion and mucosal appearances in Addison's disease and hypopituitarism. Gut, 2, 163-167.

Davidson, W. M. B., and Markson, J. L. (1955). The gastric mucosa in iron-deficiency anaemia. Lancet., 2, 639-643.

Dotevall, G. (1961). Gastric secretion of acid in diabetes mellitus during basal conditions and after maximal histamine stimulation. Acta med. scand., 170, 59-69.

Funder, J. F., and Weiden, S. (1952). The correlation between test meal findings and the histology of the stomach as shown by gastric biopsy. Med. J. Aust., 1, 600-602.

Glass, G. B. J., Speer, F. D., Nieburgs, H. E., Ishimori, A., Jones, E. L., Baker, H., Schwartz, S. A., and Smith, R. (1960). Gastric atrophy, atrophic gastritis, and gastric secretory failure. Gastroenterology, 39, 429-453.

Ihre, B. J. E. (1956). The clinical value of gastric secretion tests. Ulster med. J., 25, 1-12.

Joske, R. A., Finckh, E. S., and Wood, I. J. (1955). Gastric biopsy. A study of 1,000 consecutive successful gastric biopsies. Quart. J. Med., 24, 269-294.

Kay, A. W. (1953). Effect of large doses of histamine on gastric secretion of $\mathrm{HCl}$ : an augmented histamine test. Brit. med. J., 2, 77-80.

Kyle, J., and Stephens, F. (1961). Gastric acidity after duodenal ulcer surgery. Brit. J. Surg., 48, 465.

Marks, I. N. (1957). The significance of the gastric secretion after partial gastrectomy and gastroenterostomy with description of a method for determining the acid output. Amer. J. Gastroenterol., 27, 566-583.

- , Shurman, C. R., and Shay, H. (1959). Gastric acid secretion in diabetes mellitus. Ann. intern. Med., 51, 227-237.

Poliner, I. J., and Spiro, H. M. (1958). The independent secretion of acid, pepsin, and 'intrinsic factor' by the human stomach. Gastroenterology, 34, 196-209.

Wood, I. J., Doig, R. K., Motteram, R., Weiden, S., and Moore, A. (1949). The relationship between the secretions of the gastric mucosa and the morphology as shown by biopsy specimens. Ibid., 12, 949-958. 